\title{
Methodological and Subject Competencies of Social Studies Teachers Manifested in the Conditions of Education Digital Transformation
}

\author{
Viktoriya Khlopkova ${ }^{1},{ }^{*}$ Evgeniy Golodov ${ }^{1}$, Inna Kopchenko ${ }^{1}$, Olga Spirina ${ }^{1}$
}

${ }^{1}$ Armavir State Pedagogical University, Armavir, Russia
${ }^{*}$ Email: vikstorri@mail.ru

\begin{abstract}
The article presents the results of a study to identify the formation of methodological and subject competencies of social studies teachers in the context of digital transformation of education, which was attended by 634 teachers working in specialised classes from 7 regions of the Russian Federation. The data obtained reflect the difficulties of teachers teaching social studies related to both deficits in terms of methodological competencies and the complex, integrative content of the subject "Social Studies", requiring the teacher to be competent in various fields of knowledge. A comparison with the research results of domestic and foreign scientists was carried out. Recommendations are given to solve the identified problem: the systematic nature of identifying professional deficits of teachers in terms of the formation of methodological and subject competencies, the analysis of the most challenging topics for building individual educational routes of teachers, the further development of the mentoring system, targeted work with young teachers.
\end{abstract}

Keywords: Professional competencies, Methodological competencies, Subject competencies, Digitalisation of education, Social studies.

\section{INTRODUCTION}

The relevance of the research is determined by the key objectives of the national project "Education": ensuring the global competitiveness of Russian education, the entry of the Russian Federation into the top 10 countries of the world in terms of the quality of general education, the upbringing of a harmoniously developed and socially responsible personality based on the spiritual and moral values of the peoples of the Russian Federation, historical and national cultural traditions [1].

Modern challenges to the education system as a driver of socio-economic development, actualising the issue of quality, simultaneously increasing attention to teaching staff's activities. According to Pisareva S.A., Puchkov M.Yu., Rivkina S.V., Tryapitsyna A.P., this indicator is more than any other (the amount of funds invested in education, the size of the country, indicators of equality of educational opportunities, etc.) correlates with the results of educational activities [2]. Accordingly, it is necessary to study the factors that determine the professional portrait of a modern teacher, first of all, the assessment of professional competencies and the identification of professional deficits.

The problem of improving the quality of pedagogical activity, determining the criteria for its assessment and the content of teachers' competencies is the research subject of several Russian and foreign studies. Thus, O.V. Temnyatkina and D.V. Tokmeninova consider models for evaluating the effectiveness of teachers in the USA, China, Japan and Portugal. The authors note that the models used in evaluating teachers are based on two approaches: an assessment based on the analysis of student performance and a formative assessment of teachers. The subject of analysis in various assessment systems are teacher self-assessment, assessment within the professional community and based on public opinion, exam performance of students, professional development 
and career growth, degree of participation in school educational projects, planning skills, classroom management, pedagogical reflection, etc. [3].

Margolis A.A. notes that high-quality educational systems are based on such priorities as increasing the attractiveness of the teaching profession, high-quality pedagogical education, independent assessment of the formation of professional competencies of graduates, support for young professionals, reliance on an evidencebased scientific approach to solving professional problems of teachers, an effective system of professional development, the creation of attractive conditions for remuneration and career growth, active involvement of teachers in the process of reforming all aspects of their professional activities [4].

The authors Piskunova E.V. and Zair-Bek E.S. compare large-scale international studies of teachers' professionalism, such as TEDS-M, NorBa, TALIS, SABER-Teachers, allowing to determine the most relevant areas of professional activity of a teacher. The first two are devoted to assessing the quality of training of future teachers of mathematics and school practice, including self-assessment. The other two studies have a broader coverage of the entire education system. In general, the researchers themselves note that currently there are no such ways to evaluate the teacher's work, with the help of which it is possible to reflect the entire range of teacher's activities, therefore, "to build a qualitative examination of the teacher's professionalism, it is necessary to understand the possibilities, boundaries and conditions for the application of a particular approach or tool." At the same time, the assessment of teacher competencies should be considered in the context of educational policy and contribute to the career growth of teachers [5].

When studying the formation of key competencies and the presence of professional deficits in Russian teachers, the data from international studies such as TALIS and SABER-Teachers may be the most useful. TALIS has been conducted by the Organisation for Economic Cooperation and Development every five years since 2008 to provide objective comparative data that allows countries to determine policies to improve the quality of education. During the survey of 20 randomly selected teachers of general education organisations, information about professional training, pedagogical activity, job satisfaction, features of teaching in a multicultural environment, school climate, etc., is studied [6]. The study of the teachers' situation is also carried out in the SABER-Teachers program, carried out on the World Bank initiative [7].

Analysing the publications of foreign authors, we can note the growing popularity in the last decade of the use of methods and techniques of formative assessment of the process of pedagogical activity. Thus, according to Chen W., Mason S., Stanistszewski C., Upton A., Valley M., the leading directions for monitoring and formative evaluation of pedagogical activity are the content of teaching, the structure of educational materials, the organisation of students and the assessment of the learning process [8].

Ingvarson L., working on the problems of teachers' career growth, compliance of their professionalism with the requirements of national standards in Australia, focuses on the internal motivation of teachers to improve their professionalism, but at the same time emphasises the importance of a systematic educational policy. The author draws attention to the need for feedback from teachers on the results of research [9].

Recently, there have been studies devoted to assessing the readiness of teachers to implement labour functions in the conditions of the current educational situation. Such authors as Aigunova O.A., Vachkova S.N., Remorenko I.M., Semenov A.L., Timonova E.N., Altynnikova N.V., Muzavev A.A. and others note that currently, a significant percentage of Russian school teachers have significant professional difficulties [10]. This, in turn, requires the development of conditions for professional growth, mechanisms for targeted, personalised assistance to practising teachers based on research conducted on the problems of readiness of modern teachers to work in a new Russian school. The researchers also note that the main components of a teacher's professional competence are competencies in the subject area and discipline teaching methods [11].

The above has determined the purpose of our research - to identify the formation of methodological and subject competencies of social studies teachers working in specialised classes of various orientations. The category of respondents identified teachers teaching the academic subject "Social Studies", which, according to the concept of teaching this subject, should be presented at a basic level in all profiles, as it contributes to the socialisation of students, the formation of knowledge and practical skills necessary in modern society, as well as an active civic position.

\section{RESEARCH METHODOLOGY}

In April - October 2021, the study involved 634 social studies teachers in specialised classes of various directions from 7 regions of the Russian Federation: Belgorod Region, Volgograd Region, Krasnodar Territory, Lipetsk Region, Rostov Region, Stavropol Territory, Chechen Republic. The survey of teachers was conducted online.

Methodological competence is one of the most significant components of professional competence. The teacher's knowledge of teaching methods and techniques serves as the basis for effective professional activity and contributes to improving the quality of education. 
The tasks of the questionnaire were compiled taking into account the requirements of professional and educational standards to identify the possession of such labour actions as the implementation of professional activities following the requirements of the federal state educational standard of secondary general education, planning and conducting training sessions, the formation of universal educational actions, the development and implementation of programs of academic disciplines, the organisation, monitoring and evaluation of educational achievements.

The tasks of the questionnaire to identify the formation of subject competencies were developed based on the content of the concept of teaching the subject "Social Studies" in educational organisations of the Russian Federation implementing basic general education programs in secondary school, and reflect the thematic blocks of the subject "Social Studies".

In the study, the authors applied a set of theoretical, practical and mathematical methods of scientific cognition, such as a survey using semi-closed and closed questions, registration, rating evaluation, data generalisation, statistical data processing, mathematical data processing.

\section{RESEARCH RESULTS}

\subsection{Implementation of professional activities by respondents following the requirements of the federal state educational standards of preschool, primary general, basic general, secondary general education}

Most of the respondents - $66 \%$ answered correctly to the question "What are the requirements for a modern lesson?". Moreover, considering the length of teaching experience, this indicator demonstrates a high level of knowledge of the Federal State Educational Standard requirements for teachers' professional activity from more experienced teachers. For teachers whose experience is up to 10 years, this indicator is $60 \%$. Teachers with experience of 10 years and above demonstrated knowledge on this issue $-70 \%$.

\subsection{Implementation by respondents of planning and conducting training sessions}

$70 \%$ of respondents coped with the typology of lessons on FSES. In the context of teaching experience (work experience), the indicators are as follows: among teachers with work experience up to 10 years - 63\%, among teachers with experience of 10 years and above $75 \%$. Also, teachers needed to determine the distinctive features of the technological map of the lesson. Only $30 \%$ of respondents coped with this task. In the context of teaching experience (work experience), the indicators are as follows: among teachers with work experience up to 10 years $-26 \%$, among teachers with experience of 10 years and above $-34 \%$.

\subsection{Formation by respondents of universal educational actions among students}

Teachers were asked to determine the universal educational actions for each form (cognitive, regulatory, communicative and personal). Almost half of the respondents correctly identified cognitive universal educational actions, which is $49 \%$. Regulatory universal educational actions correctly identified $68 \% .289$ people correctly noted the communicative universal educational actions, which is $45 \%$. Personal universal educational actions were correctly indicated by $48 \%$ of respondents. Only $22 \%$ of respondents were able to arrange the stages of formation of social information skills in the correct order.

\subsection{Development and implementation by respondents of programs of academic disciplines within the framework of the basic general education program}

The choice of correct judgments about the content of social science material caused difficulties for most teachers: $33 \%$ of respondents indicated 2 and 3 correct answers, 34\% indicated 1 correct answer. The others made more than one mistake.

\subsection{Respondents' knowledge of forms and methods of teaching, including those that go beyond the scope of training sessions}

We asked teachers to answer the question: "What methods of obtaining new knowledge do you use?". The survey results showed that teachers use all the methods proposed as answer options for obtaining new knowledge: information retrieval, observation, comparison, reading. At the same time, most respondents in their work most often use such methods of acquiring new knowledge as information retrieval - $61 \%$, the comparison method - $76 \%$, the observation method $49 \%$.

\subsection{Fundamentals of teaching methods, basic principles of the activity approach, types and techniques of modern pedagogical technologies used by respondents}

When answering the question about the use of innovative educational technologies aimed at activating the independent work of students, the survey participants pointed to the use of all the proposed educational technologies (project-based learning, problem-based learning, block-modular learning, the development of 
critical thinking). At the same time, $76 \%$ of the total number of respondents confirmed the use of problembased learning technology; $70 \%$ of respondents confirmed the use of project-based learning technology; $57 \%$ confirmed the use of critical thinking technology. And only $22 \%$ of respondents confirmed the use of blockmodular learning technology. The principles of selecting material for the lesson of the social science cycle were correctly indicated by $52 \%$ of respondents. It should be noted that $67 \%$ of the correct answers were given by teachers with 10 years of teaching experience.

\subsection{Respondents' answers characterising the knowledge of normative documents on the education and upbringing of children and youth}

Respondents were asked to choose documents that are normative in the study of social studies. Only $27 \%$ of respondents coped with the task.

\subsection{Respondents' answers characterising their knowledge of basic social science concepts and terms}

Choosing the right judgments about the formation of social science concepts, only $17 \%$ of the total number of respondents correctly chose 2 correct answers. 1 the correct answer was indicated correctly by $52 \%$ of the respondents. Couldn't choose the correct $3 \%$.

\subsection{Respondents' answers characterising their legal knowledge.}

Answering the question, which of the topics will be normative for social studies at school, $38 \%$ of respondents answered the question correctly. 57\% made mistakes in the answer. All answers were indicated incorrectly by $4 \%$ of respondents.

\subsection{Respondents' answers characterising their knowledge about the social sphere of society}

Answering the question about the features of modern stratification of society, $61 \%$ of the respondents gave the correct answer, $38 \%$ gave incorrect answers.

\subsection{Respondents' answers characterising the concept of cognition as a fundamental process}

When answering the question "What distinguishes scientific knowledge from other types of knowledge", only $20 \%$ of respondents coped with the task. $9 \%$ did not specify the correct answers. The remaining respondents (71\%) made mistakes in the answer.

\subsection{Respondents' answers describing their economic knowledge}

Social studies teachers have particular difficulties in setting goals when studying the functioning of the banking system, which was revealed in the framework of the question "Among the tasks of the lesson on the topic "Banking system" in the 10th grade at the basic level of training are set correctly." This question revealed the ability of teachers to formulate the purpose and objectives of the lesson correctly. $77 \%$ of respondents fully or partially completed the task. All responses indicated 23\% incorrectly. Naming measures that contribute to reducing inflation, only $25 \%$ of respondents indicated all the correct answers, 32\% indicated all the answers incorrectly, $43 \%$ made mistakes when choosing an answer.

\subsection{Respondents' answers characterising their knowledge of the political system}

$94 \%$ of the teachers participated in the survey fully or partially coped with the question "Find the political functions of the modern state in the list below".

\subsection{Respondents' answers characterising their knowledge of current trends and patterns of development of the Russian Federation as a democratic rule of law state}

Answering the question about the number of subjects in the Russian Federation at the moment, $29 \%$ of respondents indicated the wrong number of subjects of the Russian Federation, which indicates the lack of a clear idea of the current changes in the state structure of the country. To the question "List the federal projects of the National Project "Education" known to you," teachers gave an honest answer. Various answers were given, which are difficult to imagine in percentage terms due to their diversity. Still, it can be judged that a significant part of social studies teachers have no clear ideas about the structure and content of the national project "Education".

\section{RESULTS DISCUSSION}

According to the study results, the analysis of the formation of methodological and subject competencies of teachers of social studies was carried out concerning the professional standard "Teacher" requirements in terms of knowledge and skills necessary for implementing the teacher's labour actions. The results obtained allow us to draw the following conclusions: several tasks caused difficulties for teachers, but at the same time, in the context of teaching experience (work experience), more experienced teachers made fewer mistakes. At the same time, a more significant number of respondents $(63 \%)$ have experience of 10 years or more. This also correlates 
with the data obtained in the framework of the international TALIS study in 2018, according to which Russian teachers are the most experienced, the work experience of a Russian teacher is on average 21 years, which is five years more than the average for the study as a whole.

Within the framework of the "National Research on the quality of Education NRQE-2020", including social studies, it was concluded that, as a rule, higher results of performing diagnostic tasks are shown by those students whose teachers have a long experience of pedagogical work [12].

The social studies teachers coped best with the tasks reflecting the formation of methodological competencies in terms of performing the following labour actions: carrying out professional activities following the requirements of the Federal State Educational Standard of Secondary General Education, planning and conducting training sessions. The teachers demonstrated knowledge of the basics of the teaching methodology of the subject, the basic principles of the activity approach, types and techniques of modern pedagogical technologies, possession of forms and methods of teaching, including those that go beyond the scope of training sessions.

A comparative characteristic can be carried out to analyse methods and technologies of pedagogical activity. When identifying knowledge of the basics of teaching methodology, principles of the activity approach, types and techniques of modern pedagogical technologies, the survey participants indicated the use of all the proposed educational technologies (project-based learning, problem-based learning, block-modular learning, critical thinking development), while indicating additional educational technologies not listed in the list. At the same time, the most widely used technologies are problem-based learning, project-based learning, and critical thinking development technology. According to TALIS in 2018, about $60 \%$ of Russian teachers often or always give tasks that require students to think critically, $42 \%$ of teachers say that their students work in small groups to find a joint solution to a problem; $45 \%$ of teachers ask students to choose ways to solve complex problems independently; $58 \%$ of teachers give tasks for which there is no obvious solution [13]. I.e., Russian teachers, including social studies teachers, actively use methods and technologies to develop students' cognitive activity.

At the same time, the issues that test the knowledge of normative documents on the education and upbringing of children and youth, the definition of forms of universal educational actions, were problematic. Difficulties in determining the correct judgments about the content of the social science material indicate deficiencies in the methodological competencies necessary for implementing the labour action required to develop and implement the curriculum of the discipline "Social Studies".

Probably, it is necessary to clarify the requirements of the professional standard "Teacher" in terms of teachers' possession of the required professional terms by analogy with the European professional standards of teachers, for example, in the UK, an essential component of which is "understanding" - understanding the methodology of teaching the subject, understanding the individual and age characteristics of student development, etc. The structure of these standards includes a glossary of necessary professional terms, including basic terminology [14].

Summarising the study results, we can conclude that there are professional deficits in terms of the formation of methodological and subject competencies of social studies teachers working in specialised classes of various orientations. Accordingly, it is necessary to continue research in this area in teaching social studies and develop recommendations to eliminate these deficits.

\section{CONCLUSIONS}

Based on the results of the conducted research aimed at identifying the formation of professional competencies of social studies teachers (methodological and subject competencies), conclusions were drawn related to the implementation of the following recommendations:

1. The identification of professional deficits of teachers in terms of the formation of methodological and subject competencies should be systematic.

2. A deeper analysis of the most complicated topics is needed to build individual educational routes for teachers working in specialised classes of various directions to eliminate the identified deficits.

3. The analysis of several issues, considering the experience of the pedagogical activity, showed that experienced teachers coped better with the tasks. Accordingly, it is necessary to develop further the mentoring system, targeted work with young teachers.

\section{FINANCING}

The article is prepared based on the results of the stage of scientific research of the phenomenon of continuous pedagogical education in the conditions of its digital transformation: content, technologies, quality management, risk monitoring, carried out at the expense of the federal budget within the framework of the state task of the Ministry of Education of the Russian Federation (Agreement No. 073-03-2021-012 of 18.01.2021). 


\section{REFERENCES}

[1] Passport of the national project "Education", approved by the Presidium of the Council under the President of the Russian Federation for Strategic Development and National Projects (Protocol No. 16 dated 12/24/2018) [Pasport nacional'nogo proekta «Obrazovanie», utverzhden prezidiumom Soveta pri Prezidente Rossijskoj Federacii po strategicheskomu razvitiyu i nacional'nym proektam (protokol ot 24.12.2018 № 16).]. Retrieved from: http://government.ru/info/35566/

[2] S.A. Pisareva, M.Yu. Puchkov, S.V. Rivkina, A.P. Tryapitsyna, Model of level assessment of professional competence of a teacher [Model' urovnevoj ocenki professional'noj kompetentnosti uchitelya] // Science for Education Today 9(3) (2019) 151-168. DOI: https://doi.org/10.15293/2658-6762.1903.09

[3] O.V. Temnyatkina, D.V. Tokmeninova, Models for evaluating the effectiveness of teachers' work in foreign countries [Modeli ocenki effektivnosti raboty pedagogov, ispol'zuemye $\mathrm{v}$ zarubezhnyh stranah] // Prospects of science and education [Perspektivy nauki i obrazovaniya] 3(39) (2019) 489-499.

DOI: https://doi.org/10.32744/pse.2019.3.37

[4] A.A. Margolis, Teacher qualification assessment: review and analyse the best foreign practices [Ocenka kvalifikacii uchitelya: obzor $\mathrm{i}$ analiz luchshih zarubezhnyh praktik] // Psychological Science and education [Psihologicheskaya nauka i obrazovanie] 24(1) (2019) 5-30. DOI: https://doi.org/10.17759/pse.2019240101

[5] E.V. Piskunova, E.S. Zair-Bek, Teacher's professionalism: methodology of international studies [Professionalizm uchitelya: metodologiya mezhdunarodnyh issledovanij] // The world of science, culture, education [Mir nauki, kul'tury, obrazovaniya] 5(78) (2019) 192-193. Retrieved from:

https://cyberleninka.ru/article/n/professionalizmuchitelya-metodologiya-mezhdunarodnyhissledovaniy

[6] Report on the results of the international study of the teaching staff on teaching and learning talis-2018 (Teaching and learning international survey) Part 2, Continuous training of teachers and school principals [Otchet po rezul'tatam mezhdunarodnogo issledovaniya uchitel'skogo korpusa po voprosam prepodavaniya i obucheniya talis-2018 (Teaching and learning international survey) CHast' 2. Nepreryvnoe obuchenie uchitelej i direktorov shkol], Moscow, 2019. Retrieved from: https://fioco.ru/Talis-18-results-2

[7] The World Bank Group, 2014, Teachers from Russia: SABRE country Report for 2014 [Gruppa Vsemirnogo banka, Uchitelya iz Rossii: Stranovoj otchet SABRE za 2014 god]. Retrieved from: https://openknowledge.worldbank.org/handle/1098 $6 / 23001$

[8] W. Chen, S. Mason, C. Stanistszewski, A. Upton, M. Valley, Assessing the quality of teachers' teaching practices. Educational Assessment, Evaluation and Accountability 24 (2012) 22-41. Retrieved from: http://dx.doi.org/10.1007/s11092$\underline{011-9134-2}$

[9] L. Ingvarson, Comments on the Productivity Commission Draft Research Schools Workforce Report. Retrieved from: https://www.pc.gov.au/inquiries/completed/educati on-workforce-schools/submissions/subdr067.pdf.

[10] O.A. Aigunova, S.N. Vachkova, I.M. Remorenko, A.L. Semenov, E.N. Timonova, Evaluation of the professional activity of a teacher following the professional standard of a teacher [Ocenka professional'noj deyatel'nosti uchitelya v sootvetstvii $\mathrm{s}$ professional'nym standartom pedagoga] // Bulletin of the Moscow City Pedagogical University. Series: Pedagogy and Psychology [Vestnik Moskovskogo gorodskogo pedagogicheskogo universiteta. Seriya: Pedagogika i psihologiya] 2(40) (2017) 8-23. Retrieved from: https://vestnik.mgpu.ru/index2.php?param=GtLf3u $\underline{\text { Gi }}$

[11] N.V. Altynnikova, A.A. Muzaev, Assessment of subject and methodological competencies of teachers: the approbation of unified federal evaluation materials [Ocenka predmetnyh i metodicheskih kompetencij uchitelej: aprobaciya edinyh federal'nyh ocenochnyh materialov]. DOI: https://doi.org/10.17759/pse.2019240102

[12] National Research on the quality of Education NRQE-2020 [Nacional'nyh issledovanij kachestva obrazovaniya NIKO-2020]. Retrieved from: https://fioco.ru/reports-niko

[13] Report on the results of the international study of the teaching staff on teaching and learning talis-2018 (Teaching and learning international survey) Part 1 , Continuous training of teachers and school principals. Moscow [Otchet po rezul'tatam mezhdunarodnogo issledovaniya uchitel'skogo korpusa po voprosam prepodavaniya i obucheniya talis-2018 (Teaching and learning international survey) CHast' 1. Nepreryvnoe obuchenie uchitelej 
i direktorov shkol], 2019. Retrieved from: https://fioco.ru/Talis-18-results

[14] O.H. Miroshnikova, Professional standard of a teacher: international experience and regional components [Professional'nyj standart pedagoga: mezhdunarodnyj opyt i regional'nye komponenty] //Online journal "Science Studies" [Internet-zhurnal «Naukovedenie»] 7(3) (2015) 5. DOI: https://doi.org/10.15862/53PVN315 